University, UK). Previous workshop accomplishments are reported by Armand (2006), Assmy (2008) and Leventer et al. (2007).

In addition to PAGES, the workshop was also supported by the ARC Research Network for Earth System Science, the
Australian Marine Geoscience Office, Geoscience Australia, the Australian Biological Resources Study, Macquarie University, ATA Scientific and ANDRILL.

Selected references

Full reference list online under: http://www.pages-igbp.org/products/newsletters/ref2012_1.pdf

Falkowski PG et al. (2004) Science 305: 354-360

St. John K (2008) Paleoceanography 23, doi:10.1029/2007PA001483 Stickley et al. (2009) Nature 460: 376-379

Uhen MD (2007) The Anatomical Record 290: 514-522

Zachos J et al. (2001) Science 292: 686-693

\title{
Climate change in the Carpathian-Balkan region during the Late Pleistocene and Holocene
} $1^{\text {st }}$ International Workshop, Suceava, Romania, 9-12 June 2011

Marcel Mindrescu

Department of Geography, University of Suceava, Romania; marcel.mindrescu@gmail.com

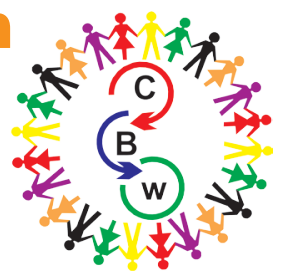

$T^{T}$ he Carpathian Mountains are considered as one of Europe's last "wilderness" areas, but are nevertheless under heavy pressure from human activities. Examples range from large-scale activities (e.g. sulfur mines in Calimani), ecological disasters (e.g. tailing dam failures in the Toroiaga and Baia Mare areas) to cross-border pollution (e.g. Chernobyl nuclear accident). The current political thrust for development is accelerating the pace of industrial activities, exploitation of natural resources and tourism.

Romania has just recently been integrated into the European Union and many community-based projects were initiated to evaluate problems related to climatic and anthropogenic impacts. However, the Carpathian Mountains remain the least studied mountain range in Europe. This paucity of research projects in the region is reflected by the low number of well-dated and high-resolution paleo-records (e.g. Buczkó et al. 2009, Fig. 1). Rose et al. (2009) published a pollution history study from a lake in the Retezat Mountains at the western extremity of the Southern Carpathians, but no similar studies exist for the rest of the mountain range, despite the abundance of lakes (Akinyemi et al., in press).

The purpose of this workshop was to bring together an international group of scientists interested in the Carpathian-Balkan region to discuss research results and promote opportunities for interdisciplinary and international collaboration. The workshop was cosponsored by the University of Suceava, the Applied Geography Association (GEOCONCEPT), the Mountain Research Institute (MRI) and PAGES.

The program centered on oral and poster presentations as well as open discussions on the climatic and environmental dynamics during the Pleistocene and Holocene in the Carpathian and Balkan mountains. The workshop featured 36 talks and 15 posters. The 70 participants were from Romania, Hungary, Germany, United Kingdom, Bulgaria, Slovenia, Ukraine,

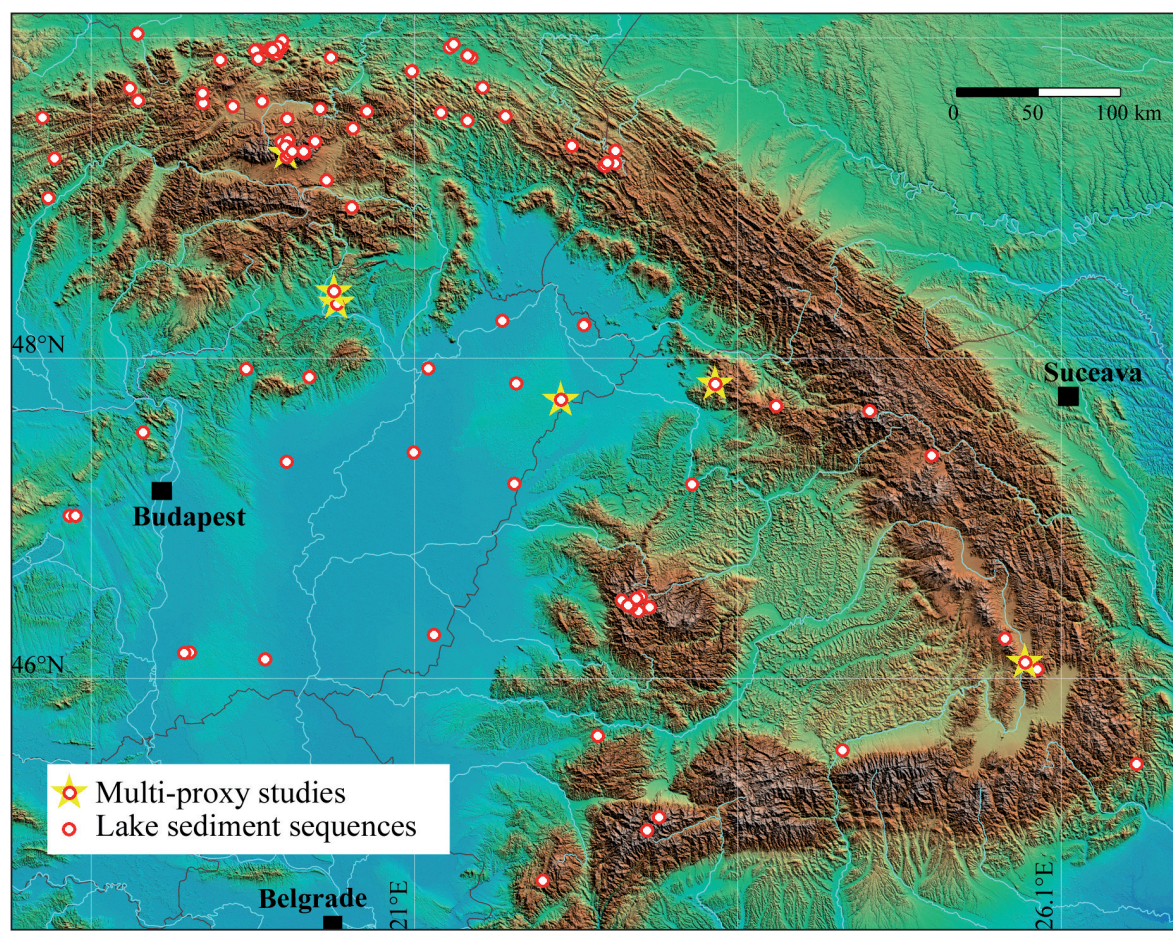

Figure 1: Map showing all sedimentary sequences identified in the Carpathian mountain range by Buczkó et al. (2009) in their review of dated Late Quaternary paleolimnological records. Despite the relative density of records listed in that study, the authors conclude that only very few records can be used for modern environment or climate studies, and that large areas of the Carpathian mountains remain under-investigated. Figure modified from Buczkó et al. (2009)

Poland, Switzerland, Czech Republic and Belgium. The entire workshop was webcast and it was educational for young researchers and students by providing them a platform to present their results to an international audience and discuss their research in a multidisciplinary community.

A post-symposium field trip was organized to the formerly glaciated alpine ranges of the Northern Romanian Carpathians (Rodna Mountains), as well as to several large peatbog accumulations and wetland ecosystems (lezer lake and Poiana Stampei peat bog).

The organizers of the workshop offered to lead publication of the more advanced workshop contributions in a special issue of the journal Quaternary International and 29 author groups committed themselves to contribute papers.
In order to promote follow-up activities in the region, the "Suceava working group" was created under the lead of Marcel Mindrescu, Angelica Feurdean, Enikő Magyari and Dan Veres. A group website is currently being set up (http://atlas.usv.ro/www/climatechange/) and grant proposals will be prepared. The group will also coordinate the organization of a second regional workshop in 2013 or 2014. Further activities, such as summer camps or meetings in the field will also be considered.

\section{References}

Akinyemi F0, Hutchinson SM, Mindrescu M and Rothwell JJ (in press) Quaternary International, doi: 10.1016/j.quaint.2012.01.022 Buczkó K, Magyari EK, Bitušík P and Wacnik A (2009) Hydrobiologia 631: $3-28$

Rose NL et al. (2009) Advances in Limnology 62: 319-350 